Article

\title{
Family Female Executives and Firm Financial Performance
}

\author{
Pilar Giraldez-Puig *(D) and Emma Berenguer \\ Department of Financial Economics and Accounting, Universidad Pablo de Olavide, 41013 Sevilla, Spain; \\ ebercar@upo.es \\ * Correspondence: mpgirpui@upo.es; Tel.: +34-954-348-986
}

Received: 10 October 2018; Accepted: 9 November 2018; Published: 12 November 2018

\begin{abstract}
The aim of this paper is to analyze the relationship of family executive women with firm performance in family firms. We have obtained a final sample of 269 family and non-family firms (comprising 3073 firm/year observations) from the Spanish High Council of Chamber (SHCC) website, while data were collected from System for Analysis of Iberian Balances database (SABI) for the period 2000 to 2011. Applying a generalized method of moments (GMM) panel data methodology, we observe a positive effect on the return on assets (ROA) depending on the existence of family ties of executive women. Several implications for the career development of women in family firms arise from our results.
\end{abstract}

Keywords: gender equality; family firms; family involvement

\section{Introduction}

The role of women in the labor force and their access to managerial positions has been receiving increased attention in recent years. Although women account approximately for $50 \%$ of the labor force in developed countries, these figures are not reflected at senior levels in the business world [1]. The United Nations have identified gender equality as a priority in their development policies and have included it as a main goal in the 2030 Agenda for the sustainable development.

Gender equality in leadership positions has both social and ethical implications for society. Aware of this situation, many European countries have established minimum quotas for female representation following a European Directive to improve women's access to boards of directors. However, parity is still far from having been achieved.

The topic has also caught the attention of academic research and a growing body of studies has focused on the economic results of having women taking decisions. Most of the literature has concentrated on the relationship between the presence of women on boards and firm performance. Results, however, are inconclusive. Some studies found a positive relationship [2-4] while others found a negative impact on firm performance.

The presence of women in top management positions and its impact on firm performance has been much less studied. The topic is of interest given that non-public firms sometimes have an informal board of directors and that most board members are not directly involved in the company's management. Within this research line, a positive relationship between the presence of executive women and firm performance seems to have been demonstrated [5-9].

The study of female executives in family businesses is of specific relevance. First, family firms are the most common type of company: worldwide, they account for over two-thirds of all companies and generate $50-80 \%$ of employment in most countries. Furthermore, women reach executive positions more in family businesses. Despite these facts, the study of female leadership and its impact on firm performance in family firms has not received much attention. The literature on women's involvement 
in family firms essentially targets three main aspects: the entry of women in family firms through entrepreneurship and succession, the career development of women in family firms, and women's static presence in family firms [10].

In family firm contexts, the manager's family status is key. Major research lines have focused on whether the chief executive officer (CEO) is or is not a family member [11-14] and participation of family members in the top management team (TMT) $[15,16]$. Nevertheless, few studies have combined manager family status in family firms with gender [17]. The main goal of this paper is therefore to study the family status of female managers and its relationship with firm performance. Establishing a causal relationship between both variables is challenging. A firm's governance team characteristics are not exogenous random variables $[6,18,19]$. Two sources of endogeneity are considered to bias the existing association. First, omitted variables, such as corporate attitudes towards women leadership, may simultaneously affect firm performance and the female manager appointment process. In this regard, several control variables with extensive use have been considered. Second, is reverse causality, where according to this discussion, some firms may have hired a high proportion of female managers because these firms are currently doing well and may be able "to take the risk" of employing female managers [6].

Therefore, taking into account these endogeneity issues, we employ a dynamic panel system generalized method of moments (GMM) estimator to estimate a dynamic model of financial performance. Our results confirmed that female executives that are family members of the founding family have a positive impact on firms' financial performance. These results seem to demonstrate that the family status of women managers may influence a company's commitment and alignment of interests. Another contribution of the study is that it focused on family female executives in Spain. To the best of our knowledge, this is the first study to have analyzed female executives that are family members and their relationship with economic results in this country.

Spain is an interesting case study for several reasons. First, a total of $45.5 \%$ of Spain's labor force is made up of women, but this percentage declines in managerial positions. According to Grant Thornton [20], women account for $26 \%$ of management positions in Spain. Moreover, female employment in Spain has risen markedly over recent years, from 32.5\% in 1995 to 51\% today. However, despite this important increase, female employment in Spain is still below the OECD average (57.5\%). Second, family companies represent $90 \%$ of total businesses in Spain and generate $70 \%$ of employment in the private sector. These figures suggest that family businesses constitute the backbone of the Spanish economy, thus justifying the study of these types of businesses.

The study was based on a sample of 269 Spanish firms. The sample has been provided by the Spanish High Council of Chamber (SHCC) website. Financial and accounting information and Corporate Governance Information has been obtained from System for Analysis of Iberian Balances (SABI).

The remainder of the paper is structured as follows: Section 2 is dedicated to the development of the hypotheses and the methodology; results are described in Section 3, and the main conclusions and discussion are presented in Section 4.

\section{Materials and Methods}

\subsection{Female Executives and Firm Performance in Family Firms}

The incorporation of women into the corporate governance structures has become a relevant topic in recent years, especially since national and international regulations appeared. It is a fact that women remain consistently underrepresented in the upper management echelons of firms. The progressive incorporation of women into managerial positions has been one of the relevant aspects of good corporate governance. To prove the benefit for the firms of having women in management positions has been a trending topic in academic research. Especially, the study of the impact of female leadership on firm level performance is a key issue. 
Unfortunately, there is no coherent theoretical framework that comprises all aspects of gender and how it could affect firm performance, although the resource-based theory has claimed for the outperform of women in managerial positions. According to Barney [21], resource-based theory argues that human capital resources are key to competitive advantage. Employee and management capabilities are firm-level resources that are difficult for competitors to imitate. Katzenbach et al. [22] concluded that many companies have underutilized human resources by not including women and minorities.

This theory suggests that firms employing more women managers have probably better succeeded at recruiting capable managers from the total available talent pool. Nevertheless, literature addressing the links between firm performance and female presence in governance is inconclusive, especially in the context of female presence on boards of directors. In this latter case, literature is mainly based on large and listed companies, and according to Carter et al. [23], the net effect of gender diversity can be either positive or negative from a financial performance perspective depending on the different internal and external circumstances of the firm. The existing literature seems to confirm this idea.

Numerous studies find a positive relationship between women on boards and firm performance [24]. More recently, Terjesen et al. [24] conducted a study on 3876 public firms in 47 countries and found that firms with female directors have better financial performance. On the contrary, Shrader et al. [5] analyzed the participation of women on the boards of 200 large U.S. firms found a negative impact on performance. Adams and Ferreira [25] for a sample of U.S. firms found that the average effect of gender diversity on firm performance was negative. He and Huang [26] also found a negative link for 530 U.S. manufacturing firms.

In Europe, the Scandinavian countries have been a pioneer in gender issues and the different studies show, as well, no consensus in their results. Smith et al. [6] and Nielsen and Huse [27] found positive effects, while Randoy et al. [28] and Rose [29] did not find a significant diversity effect on a firm's performance.

More recently, Masud et al. [30] examined a sample of companies in South Asian countries and did not find any significant relationship between female directors and the Environmental Sustainability Reporting Performance (ESRP). This result was expected, as female participation in SA countries' board decisions is very limited compared to developed countries.

In Spain, Campbell and Minguez-Vera [31] and Martin-Ugedo and Minguez-Vera [32] obtained a positive effect between gender diversity. Nevertheless, Minguez-Vera and Martin [33] analyzed the presence of women on the board of directors in a sample of SMEs, finding a negative impact on the return on equity (ROE).

Although the board of directors is considered part of the TMT, some members are not directly involved in the management of the company and, given the small proportion of women reaching senior positions, it seemed relevant to study the relationship between executive women and firm performance, especially considering that not-public firms sometimes have an informal board of directors. Women in top management and its impact on firm performance has been much less studied.

Women bring a number of strengths and skills to the management teams. Several studies analyze different management styles between men and women [5,34,35].

Based on surveys and interviews with female leaders, Rosener [36] found that women show an interactive leadership style. They encourage participation and share power and information with their subordinates. Sandberg [37] revealed that women create a more flexible environment fostering exchange of ideas and knowledge. This style should produce positive effects on firm performance and the existing literature seems to support this idea and offers more conclusive results than those studies based on board of directors. Thus, the vast majority of the limited studies that analyzes the relationship between the presence of executive women and firm performance have found a positive influence on financial return [5-9]. So, according to this latter literature, based on executive women, we expect similar results in our sample.

Hypothesis 1. Female executives exert a positive effect on firm's return on assets (ROA). 
This topic presents additional interest in the specific case of family firms, due to the fact that the number of women that reach managerial positions is higher in the family businesses [38,39]. According to Martinez-Jiménez [40], family-owned and family-controlled businesses have higher percentages of women in the c-suite, as well as in top management positions and on the board, than other types of companies.

Despite these facts, the study of female leadership and its impact in firm performance of family firms has not received much attention. The study of Bjuggren [41] is an exception where differences in firm performance due to female leadership in family and non-family firms was analyzed and the results indicated that female leadership makes much more of a positive difference on performance in family firms while this effect is negative in non-family firms.

Campopiano et al. [10] provide a recent review of research on women's involvement in family firms and identified three main aspects addressed by literature: the entry of women in family firms through entrepreneurship and succession, women's career development in family firms, and women's static presence in family firms.

In our study, we consider that women's career development is the aspect that most affects women as executives. Traditionally, women have had preference to work in family firms. According to Dumas and Lyman et al. [42,43], family firms offer women many advantages such as flexible schedules (which help them combine their professional responsibilities with childcare), job security, more opportunities for personal growth, and greater chance to access managerial positions. Family businesses offer women opportunities that other businesses do not. For example, Salganicoff [44] reported better positions, higher income, more flexibility in work schedules, and more job security for women who work in family businesses than for women who work in non-family businesses.

Nevertheless, women also face several problems in reaching top positions even though they are now as academically qualified as male counterparts. The invisibility problems and discrimination still exist in the base of many companies, which are essentially patriarchal. This problem is even harder in a country like Spain, in which there is still a certain belief in a distribution of roles between sexes and women are supposed to stay at home taking care of the family. In this sense, there is a research line focused on the gender pay gap (GPG) among managers. Based on a sample of Spanish managers, Scicchitano [45] showed that women earned significantly less than men across wage distributions.

Based on the above, we consider that women who have access to leadership positions have had to overcome many obstacles that have made them better leaders, so we expect them to have a positive effect on firm performance. This is also consistent with the resource-based theory, which implies that human capital is the key factor for firms and it is also important in family firms. Therefore, we propose the following hypothesis:

Hypothesis 2. Female executives exert a positive effect on ROA in family firms.

\subsection{Female Executives, Family Status, and Firm Performance}

In this family firm context, the family status of the managers represents a key issue. Nevertheless, it is the object of conceptual controversy as different interpretations can be given according to the theoretical approach. Agency theory is double edged, on one hand it has been used to suggest that firms run by family executives benefit from lower agency costs because there is an alignment between owners and managers [46,47] and on the other, family executives are said to use their superior positions to benefit themselves at the expense of the company [48,49].

Furthermore, stewardship theory also applies to family firms and family leaders. It considers that family executives are especially attached and loyal to their firm. These managers are highly motivated and manage for the long-term.

Among the main issues, the most important research lines have been focused on whether the CEO is or is not a family member [11-14] and participation of family members in the TMT. The results of these studies are inconclusive. 
Nevertheless, only a few studies have related the family status of family firm managers with gender. Cromie and Sullivan [17] compared career experiences of executive women who were both family and non-family members. To do so, they interviewed 80 family women executives and 62 non-family executive women. They showed on their study that family members had advantages over non-family members in developing careers in family firms. In their study, the authors demonstrated that female managers that were family members had a long association with the family business because, generally, they had been working in the business for longer than their non-family counterparts. Family executives also experienced a sense of achievement and enjoyed job security and flexibility.

These results are consistent with stewardship theory assumptions, therefore we propose a third hypothesis:

Hypothesis 3. Executive women that are family members have a positive impact on firm performance.

\subsection{Sample}

The sample of firms used for this study was provided by the Spanish High Council of Chamber (SHCC) website, initially comprising 287 firms for the years 2000 to 2011 (twelve periods) and 3444 observations. Most of these companies were small or medium-sized and non-listed firms. The SHCC database contains Spanish exporting firms, which is particularly relevant for our study for several reasons. To begin with, companies with export activity are larger than their non-exporting counterparts, and consequently their government bodies are usually more developed [50] including regarding gender issues. Second, they have to handle a high-risk competitive environment, which makes firms economically driven and reluctant to hire low quality managers regardless of their family condition. Finally, they are also older, which in the case of family businesses, implies a second or third generation involvement in management [51], making it easier to find more family-women in governance positions. All of these features are necessary and add value to our study.

Once the firms have been identified we have used the System for Analysis of Iberian Balances (SABI), with information about company identification, industry sector (Global Industry Classification Standard, GICS), financial and accounting data, and Corporate Governance information. After discarding firms with missing values, an unbalanced panel comprising 269 companies and 3073 observations was obtained covering the period 2000-2011.

\subsection{Variables}

\subsubsection{Dependent Variable}

Return on Assets (ROA): We employed the return on assets as a proxy for accounting-based performance. This is the variable that best fits to our sample, as it is composed of non-listed firms. It is calculated as the ratio earnings before taxes to book value of assets. Accounting proxies for firm performance have been widely used, especially for non-listed firms, as there is no market information about the value of the firm $[6,11,52,53]$.

\subsubsection{Independent Variables}

Corresponding to our hypotheses, we selected three variables expecting to influence the performance of the firm:

1. Female Executive Managers (Femaleexecutive): We used a dichotomous variable indicating whether any woman has this role or not. It was given a value of 1 if there is at least one executive woman in the top management team and 0 otherwise. Our initial hypothesis was that women exert a positive influence on firm performance.

2. Family Ownership (Familyfirm): There is no concise, measurable, and widely accepted definition of family business. Nevertheless, the literature agrees that a defining feature is family involvement 
in ownership and management. According to family firm's literature, family control is the most common governance structure among family companies around the world [54]. For that reason, prior research considers that a company is a family firm when the same family owns more than $50 \%$ of the voting shares [55]. Although for listed companies this percentage declines [13]. Therefore, we included this dichotomous variable in order to control for the influence of the family on the return on assets [33]. It took the value of 1 for family firms and 0 in other cases. As stated in our second hypothesis, we expected a better performance from family businesses and thus, a positive sign.

3. Family Female Executives (Familyfemaleexecutive): For family firms, we considered the presence of executive women who belonged to the TMT being members of the founding families. In order to analyze family membership, we compared the surnames of the executives up to the second degree of consanguinity. Spain has a double-surname system (father's and mother's surname in that order), so we completed the information checking name by name. This variable took value 1 for firm/year observations with at least one family female member on the TMT. Once more we posed that family links exerted a positive influence on firm performance, as we argued in hypothesis three, so positive signs were expected.

\subsubsection{Control Variables}

In order to get the correct specification of the models, we considered a number of control variables with extensive use for these kind of studies, and that are on the disposal for small and medium enterprises. For listed firms, the literature contemplates that there are other governance variables that could be influencing the firm performance, such as market competition [56], the use of compensation incentives [57], and the mutual monitoring between managers [58], but our sample does not allow us to get such information. Specifically, we use the age of the firm (Age), the level of debt (Leverage), the logarithm of the sales (Size), the liquidity ratio (Liquidity), and eight dummy variables describing the sector in which the firm operates. These variables are defined below.

1. Firm Age (Age): The firm age variable has been measured as the number of years a firm has been in existence. It is used to control its level of experience and accumulated resources, usually the result of a long process [59]. Regarding the exporting activity, Grazzi and Moschella [60] stated that young firms are more adaptable and less affected by currency fluctuations; they also suffer less organisational rigidity. Thus, Age was expected to have a negative influence on firm performance.

2. Firm Leverage Ratio (Leverage): We attempted to control for credit constraints and capture the firm's financial stability across the leverage ratio. It has been estimated as the long-term debt/total assets ratio. The expected sign is negative given the cost of the debt, and that tax shield did not affect our dependent variable [61].

3. Firm Size (Size): Larger companies may benefit from economies of scale, so they can be more profitable and more active in developing international operation [62,63]. Hence, we anticipated a positive relationship between firm size and ROA. To measure the firm's size, Dang et al. [64] provide evidence of a better determination coefficient (R2) when using market information, but of similar results for total assets and sales as accounting figures. We measured firm size as the natural logarithm of sales given the lack of market information for non-listed companies.

4. Liquidity Ratio (Liquidity): Liquidity ratio measures a business' ability to cover short-term payment obligations, being the support of the immediate survival of an enterprise. Insufficient coverage indicates that the business might face difficulties in facing its debts. On the other hand, a trade-off exists between liquidity and long-term profitability: if funds are confined to liquid assets, they are unavailable for operations or investment purposes with higher returns, generating an opportunity cost that would affect a firm's overall profitability [65]. Therefore, we assume a negative relationship with ROA $[66,67]$. 
5. Sector and Year dummies: finally, we also included sector and time dummies in order to control the possible influence of unobservable characteristics of time-macroeconomic factors and the type of industry to which the firm belongs. Table 1 exhibits the distribution of the firm/year observations of the sample by sector.

Table 1. Sample distribution by sector classification.

\begin{tabular}{clc}
\hline Sector & \multicolumn{1}{c}{ Description } & No Firm/Year Obs. \\
\hline Sector 1 & Primary sector & 816 \\
Sector 2 & Food, beverage and textile sector & 960 \\
Sector 3 & Chemical and pharmaceutical & 180 \\
Sector 4 & industry & 949 \\
Sector 5 & Enade and manufactures & 72 \\
Sector 6 & Technological & 48 \\
Sector 7 & Consulting, education, and & 36 \\
Sector 8 & assistance & 12 \\
\hline
\end{tabular}

Note: This table shows the distribution by industry for the 3073 observations.

Table 2 below describes all explanatory variables used in our models.

Table 2. Description of the variables and expected sign.

\begin{tabular}{|c|c|c|}
\hline Variable & Description & Expected Sign \\
\hline \multicolumn{3}{|c|}{ Dependent variable } \\
\hline ROA & Earnings before taxes divided by total assets & \\
\hline \multicolumn{3}{|c|}{ Independent variables } \\
\hline Femaleexecutive & Dummy variable indicating the presence of female executive managers & + \\
\hline Familyfirm & Dichotomous variable that equals 1 if it is a family-owned firm, and 0 otherwise & + \\
\hline Familyfemaleexecutive & $\begin{array}{l}\text { Dummy variable to indicate if there are any executive women on the TMT in } \\
\text { family businesses }\end{array}$ & + \\
\hline \multicolumn{3}{|c|}{ Control variables } \\
\hline Age & Years since the firm's foundation & - \\
\hline Leverage & Long term debt/total assets & - \\
\hline Size & Natural logarithm of sales as a proxy to firm size & + \\
\hline Liquidity & Liquidity ratio measured as current assets minus inventories to short term debt & - \\
\hline Sector ${ }_{i}$ & Seven dummy variables to determine the sector the firm belongs to & \\
\hline
\end{tabular}

\subsection{Descriptive Statistics}

The main feature we found regarding female executives (Femaleexecutives) was their expected fairly low participation. Executive women accounted for 12.67 per cent of the cases analyzed, but the median value was 0 , meaning the likelihood was to find no executive women at all. Family firms prevailed, representing 60.95 per cent of the sample; non-family firms represented the remaining 39.05 per cent. This data was unsurprising, as over two-thirds of all Spanish companies are family owned.

Considering the small group of women in our sample, several key aspects are worthy of note. The main question was their representation in family firms, and we observed that most of these women were working in family businesses $(69.30 \%)$, whereas $30.7 \%$ were working in non-family firms. The $\chi^{2}$ coefficient $\left(13.467^{* * *}\right)$ in Table 3 indicates that this difference was statistically significant, so we can state that women have better opportunities in family businesses than in their non-family counterparts. For a deeper understanding of these results, we have included a frequency distribution (Table 4) that summarizes the relationship between our category variables (Familyfirm, Femaleexecutive, and Familyfemaleexecutive). Based on this table, it is possible to observe that although this could seem to be a good starting point, only $14.9 \%$ of family firms had some executive women. Even though this is a low value, it is above that found for non-family firms, where it was only $10.4 \%$. The first implication is that further progress is necessary, both in family and non-family firms. 
Table 3. Female executive and family firms' $\chi^{2}$ tests.

\begin{tabular}{cccccc}
\hline Variable & Val & df & Asymp. Sig (2 Sided) & Exact Sig (2 Sided) & Exact Sig. (1 Sided) \\
\hline Pearson $\chi^{2}$ & 13,467 & 1 & 0.000 & & \\
Continuity correction & 13,074 & 1 & 0.000 & & \\
$\quad$ Likelyhood ratio & 13,832 & 1 & 0.000 & 0.000 & \\
$\quad$ Fisher's exact tests & & & & & \\
Linear by linear association & 13,463 & 1 & 0.000 & & \\
$\quad$ N of Valid Cases & 3173 & & 0.000 & & \\
$\quad$ Pearson $\chi^{2}$ & 13,467 & 1 & &
\end{tabular}

Table 4. Female executive and family firms crosstabulation.

\begin{tabular}{|c|c|c|c|c|c|}
\hline & & & \multicolumn{2}{|c|}{ Female Executive } & \multirow{2}{*}{ Total } \\
\hline & & & 0 & 1 & \\
\hline \multirow{6}{*}{ Familyfirm } & \multirow{3}{*}{0} & \% Within Familyfirm & $89.6 \%$ & $10.4 \%$ & $100.0 \%$ \\
\hline & & $\%$ Within Femaleexecutive & $40.1 \%$ & $30.7 \%$ & $38.9 \%$ \\
\hline & & $\%$ of Total & $34.8 \%$ & $4.0 \%$ & $38.9 \%$ \\
\hline & \multirow{3}{*}{1} & \% Within Familyfirm & $85.1 \%$ & $14.9 \%$ & $100.0 \%$ \\
\hline & & $\%$ Within Femaleexecutive & $59.9 \%$ & $69.3 \%$ & $61.1 \%$ \\
\hline & & $\%$ of Total & $52.0 \%$ & $9.1 \%$ & $61.1 \%$ \\
\hline \multirow{3}{*}{\multicolumn{2}{|c|}{ Total }} & \% Within Familyfirm & $86.9 \%$ & $13.1 \%$ & $100.0 \%$ \\
\hline & & \%Within Femaleexecutive & $100.0 \%$ & $100.0 \%$ & $100.0 \%$ \\
\hline & & $\%$ of Total & $86.9 \%$ & $13.1 \%$ & $100.0 \%$ \\
\hline
\end{tabular}

Finally, regarding women who work in family firms, their family relationship with the founding family is fairly close. We found that $7.37 \%$ of women in our sample were relatives of the main owner but this represented $86.16 \%$ of the total number of women working in family firms. This indicates that in our sample, family women had better access to management positions, a finding in line with that of other studies $[57,58]$. Table 5 shows mean statistics for the variables included in the data set, and Table 6 shows the correlation matrix.

Table 5. Descriptive statistics.

\begin{tabular}{cccccc}
\hline Variable & Mean & Median & St. deviation & Minimum & Maximum \\
\hline ROA & 3.439778 & 2.56 & 15.66571 & -324 & 221.06 \\
Femaleexecutive & 0.1266996 & 0 & 0.3326876 & 0 & 1 \\
Familyfirm & 0.6094656 & 1 & 0.4879487 & 0 & 1 \\
Familyfemaleexecutive & 0.07059 & 0 & 0.25618 & 0 & 1 \\
Age & 22.03453 & 21 & 13.26250 & 0 & 91 \\
Leverage & 59.62609 & 61.12 & 25.29068 & 0 & 257.56 \\
Size & 13.69550 & 14.83 & 3.617465 & 0.8 & 20.67 \\
Liquidity & 2.25646 & 1.39 & 10.37555 & 0 & 567.52 \\
\hline
\end{tabular}

Table 6. Correlation matrix.

\begin{tabular}{|c|c|c|c|c|c|c|c|c|}
\hline Variable & ROA & $\begin{array}{c}\text { Female } \\
\text { executive }\end{array}$ & Familyfirm & $\begin{array}{c}\text { Familyfemale } \\
\text { executive }\end{array}$ & Age & Leverage & Size & Liquidity \\
\hline ROA & 1 & & & & & & & \\
\hline Familyfirm & $0.1016^{* * *}$ & $0.0635^{* * *}$ & 1 & & & & & \\
\hline $\begin{array}{c}\text { Familyfemale } \\
\text { executive }\end{array}$ & $0.0145^{*}$ & $0.3767^{* * *}$ & $0.4895^{* * *}$ & 1 & & & & \\
\hline Size & $0.1510^{* * *}$ & $0.1084^{* * *}$ & $0.0400 * *$ & 0.0210 & 0.0210 & $-0.0392^{* *}$ & 1 & \\
\hline Liquidity & 0.0231 & $0.0328 *$ & 0.0255 & 0.0483 & -0.0045 & $-0.1744^{* *}$ & $-0.0950^{* * *}$ & 1 \\
\hline
\end{tabular}

Notes: ${ }^{* * *}, * *, *$ denote significance at $1 \%, 5 \%$, and $10 \%$ levels, respectively. 


\subsection{Methodology}

The methodology was determined by taking into account two significant problems that arise when analyzing the impact of the governance structure on firm performance: endogeneity and unobservable heterogeneity. Regarding endogeneity, we found that our topic could be endogenous: because firm performs well, the family is more likely (or more easily) able to install a family female in the executive team. Therefore, we discussed an empirical specification that would solve two sources of endogeneity: omitted variables and reverse causality.

Omitted variables (both time-varying and fixed over time) may simultaneously affect firm performance and the female manager appointment process. For example, in the case of the firm's attitude towards CSR issues, the stronger the sensitivity towards CSR, the higher the presence of female managers on the TMT. Furthermore, this attitude could affect firm performance through the reduced cost of capital [59], higher valuation, and greater access to finance [60,61]. Moreover, the direction of causality between female managers and firm performance could be reversed. Women could prefer to work in family firms (or in firms with better performance), and at the same time family firms (or successfully directed firms) could prefer to establish a family female in the executive team (or to hire executive women).

To solve this problem, there exist several methods to use, basically through the use of instrumental variables; regardless, they are considered as fixed or random effects, as well as by the generalized method of moments (GMM). In this sense, we follow Li (2016) [68] who reviews all the prevailing econometric remedies concluding that among all of them, GMM has the greatest correction effect on the bias. We then proposed a dynamic panel system generalized method of moments estimator (GMM) as a suitable estimator that takes into account whether female managers (regardless of their family link to the firm) have an impact on firm financial performance.

Finally, unobservable heterogeneity occurs when calculated estimators are biased by the tendency of every firm to act in a certain unobservable manner over time or randomly. Specifically, family businesses have many characteristics that make them different from other organizational structures [69].

The generalized method of moments (GMM) not only controls for unobservable heterogeneity problems, it is also consistent with endogeneity through its use of instruments; in order to improve efficiency, the estimator developed by Arellano and Bond [70] was used, which exploits all the moment restrictions specified by the model. Specifically, we lagged twice the explanatory variables as valid instruments. In this way, we solved the endogeneity problem caused by the fact that the explanatory variables of the models and firm financial performance could be determined simultaneously. Finally, the error term was split into three components $\left(\varepsilon_{i t}=d_{t}+\eta_{i}+v_{i t}\right)$ : the time effect, $d_{t}$, the individual effect, $\eta_{i}$, and random disturbance, $v_{i t}$.

Based on these considerations, we proposed the models below to test corresponding hypotheses:

$$
\begin{aligned}
& R O A_{i t}=\beta_{1} \times \text { Femaleexecutive }+\beta_{2} \times \text { Age }+\beta_{3} \times \text { Leverage }+\beta_{4} \times \text { Size } \\
& +\beta_{5} \times \text { Liquidity }+\sum_{6}^{13} \beta_{i} \times \text { Sector }_{i}+\eta_{i}+\delta_{k}+v_{i k} \\
& R O A_{i t}=\beta_{1} \times \text { Femaleexecutive }+\beta_{2} \times \text { Familyfirm }+\beta_{3} \times \text { Age } \\
& +\beta_{4} \times \text { Leverage }+\beta_{5} \times \text { Size }+\beta_{6} \times \text { Liquidity } \\
& +\sum_{7}^{14} \beta_{i} \times \text { Sector }_{i}+\eta_{i}+\delta_{k}+v_{i k} \\
& R O A_{i t}=\beta_{1} \times \text { Femaleexecutive }+\beta_{2} \times \text { Familyfirm } \\
& +\beta_{3} \times \text { Familyfemaleexecutive }+\beta_{4} \times \text { Age }+\beta_{5} \times \text { Leverage } \\
& +\beta_{6} \times \text { Size }+\beta_{7} \times \text { Liquidity }+\sum_{8}^{15} \beta_{i} \times \text { Sector }_{i}+\eta_{i}+\delta_{k} \\
& +v_{i k}
\end{aligned}
$$


In the first model we tested the influence of female executives on the performance of the firm, expecting a positive outcome, and taking into account the possible effect of all remaining controlling variables. The influence exerted by family firms was considered in the second model. We also measured the importance of family ties with the controlling shareholder in model 3 (see Table 7). Since a stronger commitment of family female executives may in turn affect firm performance, we tested to what extent family ties of executive women were related to firm performance in model 3.

Table 7. GMM Estimation of the effect of female executive managers on firm performance.

\begin{tabular}{|c|c|c|c|c|}
\hline Notation & Variables & Model 1 & Model 2 & Model 3 \\
\hline Femaleexecutive & Female Executive Managers & $0.26682 * *$ & $0.22842 * *$ & $0.39191^{* * *}$ \\
\hline Familyfirm & Family Ownership & & $0.35740 *$ & $0.36381 *$ \\
\hline Familyfemaleexecutive & Family Female Executive Managers & & & 0.19883 * \\
\hline Age & Age of the Firm & $-0.21629 * *$ & $-0.45080^{* * *}$ & $-0.26104^{* * *}$ \\
\hline Leverage & Leverage ratio & $-0.54936^{* * *}$ & $-0.52446^{* * *}$ & $-0.54414^{* * *}$ \\
\hline Size & Logarithm of Sales & $0.07484^{* * *}$ & $0.08715^{* * *}$ & $0.07159^{* * *}$ \\
\hline Liquidity & Liquidity ratio & -0.04831 & $-0.02869 *$ & -0.028343 * \\
\hline Sector 1 & & -0.38852 & $0.36573 * *$ & 0.28657 * \\
\hline Sector $_{2}$ & & -0.5861 & $0.53239 * * *$ & $0.44752^{* * *}$ \\
\hline Sector $_{3}$ & & -0.18521 & 0.28807 & 0.33343 \\
\hline Sector $_{4}$ & Dummy variables to indicate the & -0.45487 & $0.68158^{* * *}$ & $0.62160 * * *$ \\
\hline Sector $_{5}$ & sector to which the firm belongs & -0.52181 & 0.5884 & 0.3788251 \\
\hline Sector $_{6}$ & & 0.25549 & 0.39884 & 0.323104 \\
\hline Sector 7 & & -0.82316 & $1.13473^{* * *}$ & $1.06881^{* * *}$ \\
\hline $\mathrm{m} 2$ & Serial correlation test of second order & 0.603 & 0.781 & 0.595 \\
\hline Hansen & Hansen test & $185.74(175)$ & $236.56(240)$ & $235.11(241)$ \\
\hline z1 & Wald test & $99.38(12) * * *$ & $93.29(13)^{* * *}$ & $86.58(14)^{* * *}$ \\
\hline $\mathrm{z} 2$ & Wald test & $35.61(10) * * *$ & $27.68(10) * * *$ & $27.11(10) * * *$ \\
\hline
\end{tabular}

Notes: ${ }^{* * *}, * * *$ denote significance at $1 \%, 5 \%$, and $10 \%$ levels, respectively. Variables: Female Executive Managers (Femaleexecutive): Variable indicating whether there are women as executives. It was given a value of 1 if there was at least one executive woman and 0 otherwise. Family Ownership (Familyfirm): Dichotomous variable that equals 1 if it was a family owned firm and 0 otherwise. Family Female Executive Managers (Familyfemaleexecutive): Dummy variable to indicate whether there are any executive women on TMT in family businesses. Firm Age (Age): Number of years a firm has been in existence. Leverage Ratio (Leverage): Long term debt/total assets. Firm Size (Size): Logarithm of sales volume. Liquidity ratio (Liquidity): current assets minus inventories to short term debt. Industrial Sector $\left(\right.$ Sector $_{\mathrm{i}}$ ): Dummy variables to indicate the sector to what the firm belongs; $\mathrm{m} 2$ is the serial correlation test of second order. Hansen is a test of over-identifying restrictions, asymptotically distributed as $\chi^{2}$ under the null, with degrees of freedom in parentheses; $z_{1}$ : Wald test of the joint significance of dependent variables. $z_{2}$ : Wald test for the joint significance of time dummies.

To check the potential mis-specification of the models, we used the Hansen J statistic of overidentifying restrictions to test the absence of correlation between the instruments and the error term. These statistics are shown together with the estimation results.

\section{Results}

With regard to hypothesis 1 , model 1 contained the relationship between the predictor Femaleexecutivewomen (and the rest of control variables) and ROA. The coefficient was significant at the 0.05 level, with a positive value of 0.26682 . Thus, our first hypothesis, according to which we expected a positive effect of female executives on firm's ROA, was supported. In this model, the firms age and leverage showed a negative connection with the performance and size affected positively, so our initial framework was confirmed. Liquidity showed no significant effect, and the sector to which the firm belonged seemed to have no significant effect either.

In model 2, we added a control variable for family firms. The result reinforced our initial hypothesis relating to female executives, even in family firms, which also confirmed our second hypothesis. The $\beta$ coefficient for female executives with a value of 0.22842 was once again positive and statistically significant at 0.05 . Another interesting result obtained in this model was that family firms outperformed their non-family counterparts, as the $\beta$ coefficient of the variable Familyfirm was also positive (0.35740) and significant. Moreover, as the Familyfirm dummy variable acted as an intercept, the effect of female executives on ROA in this second model was enhanced for family firms, supporting hypothesis 2 . With respect to the sector, it is worth noting that the positive and significant effect on firm 
financial performance of primary activities (sector 1), food, beverage, and textile industry (sector 2), trade and manufactures (sector 4), and consulting, education, and assistance (sector 7). These activities remained significant in model 3. One possible explanation of these results could be a higher feminine presence in these specific industries.

Regarding our third hypothesis, model 3 introduced the Familyfemaleexecutive variable, which showed a positive and significant $\beta$ coefficient of 0.19883 . This coefficient, together with both, Femaleexecutive (0.39191) and Familyfirm (0.36381), which are also statistically significant, confirmed our hypothesis 3 . Although it could be initially accepted that these women had developed their career based on family ties, in our sample, economic goals seemed to have guided their choice. Therefore, we can state that executive women who are family members have a positive impact on firms' performance. It is also remarkable that in models 2 and 3, Age, Leverage, Size, and Liquidity turned out expected signs and effects, and that four sectors (1,2,4, and 7) showed positive and significant effects, whereas the remainder seemed to have had no impact at all.

\section{Discussion and Conclusions}

Gender equality has been identified as one of the main sustainable development objectives to be met by nations. To meet this goal, the progressive incorporation of women into management positions is a key action to be undertaken in developed countries. In this task, family businesses play an essential role.

Using a sample of 269 family and non-family firms retrieved from Spanish High Council of Chamber (SHCC) website, we have observed that family firms offer women more opportunities to reach managerial positions, especially for those that are part of the family.

The family status of the manager has been receiving increasing attention in academic research though with different results depending on the studies' theoretical approach and interpretation. Agency theory suggests that firms with family managers would benefit from lower agency costs since there is an alignment of interests between managers and owners $[46,47]$ but the theory also supports the idea that some family managers use their superior position to their own interest $[48,49]$. Stewardship theory is clearer and considers that family executives are loyal to their firm and adopt a long-term perspective in their management. This theory prevails in the few studies that consider the combined factors of women managers and family [17]. Therefore, in our study, we have considered this theory for the development of the three hypotheses which have been confirmed.

According to References [5-9], our results found a positive effect of female executives on a firm's ROA. This positive effect on ROA was also valid when we controlled for family firms. This result is compatible with previous findings by Dumas and Lyman et al. [42,43] and Salganicoff [44].

Moreover, executive women that are family members positively impacted a firm's performance. These results seem to support the idea that female executives that are members of the founding family are committed to the firm. These women have been able to develop their career as managers and now enjoy their professional achievements and job security. Our results are consistent with resource-based theory and stewardship theory, following previous studies [17].

We believe our study has made several contributions. From an academic perspective, the main contribution of this paper is that, to the best of our knowledge, it is the first study to have analyzed female executives that are family members and their relationship with economics results in Spain. From a managerial point of view, the main contribution of this paper is how family businesses seem to enhance the career of women in management positions, especially those of the members of the founding family. Women seem to find a "friendly" environment in family business that makes them feel committed to the business and helps them build their career.

There are a number of practical implications of this study. First, our study has implications for women's career development in family firms. Given women's significant participation in family firms, it would be advisable that firms design programs directed towards developing executive women careers. Mentoring programs to help women reach the upper echelons of the organizations would 
be decisive. Second, as female participation in management bodies leads to better performance, firms should be encouraged to increase the participation of women in governance structures. The implementation of educational and training programs, including aspects of life balance, could be helpful in this regard. Third, the Spanish government has promulgated a series of laws (Gender Equality Act 2007, Law 31/2014 and the New Good Governance Code in 2015) relating to the corporate governance of listed companies, but no regulations have been advanced for non-listed companies and small and medium enterprises (SMEs). It would be desirable that policymakers issue guidelines directed towards these types of firms, establishing the need to include women in government bodies, as they may increase companies' value. Finally, overall, this paper considers the importance of gender equality on firm's government bodies, not only as a means for gaining social legitimation, but also for a firm's succeed. United Nations has focused its fifth Sustainable Development Goal on gender equality and women's empowerment because they are conscious that women's disadvantages in governance positions translate into firm's lack of access to female skills and limited opportunities. Therefore, this paper contributes to deliver the message that women perform well, and that this result is enhanced for female members of the founding family, which is something still bizarre to some extent not only in developing but also for the case of developed countries, where gender constraints for a possible pregnancy, time to care the family, or lower leadership capabilities still persist.

It is worth noting that the study is limited to a single country: Spain. However, Spain does not differ significantly from its neighboring countries, so results could be generalized to a certain extent to managers in other countries. Nevertheless, further research is needed in order to consider a wider spectrum of socioeconomical environment. Furthermore, the inclusion of variables to measure the professionalisation of executives could help develop our understanding of how family ties represent a constraint for executive women. It is also necessary to study non-family women executives.

Author Contributions: Conceptualization, P.G.-P. and E.B.; data curation, P.G.-P. and E.B. Formal analysis, P.G.-P. and E.B.; Investigation, P.G.-P. and E.B.; methodology, P.G.-P. and E.B.; resources, P.G.-P. and E.B.; writing-original draft preparation, P.G.-P. and E.B.; writing—review and editing, P.G.-P.; project administration P.G.-P. and E.B.

Funding: This research received no external funding.

Acknowledgments: The authors are very grateful to the reviewers for their careful reading of the paper.

Conflicts of Interest: The authors declare no conflict of interest.

\section{References}

1. Catalyst. Quick Take: Statistical Overview of Women in the Workplace; Catalyst: New York, NY, USA, 2017.

2. Carter, D.A.; Simkins, B.J.; Simpson, W.G.; Borokhovich, K.; Crutchley, C.; Elson, C.; Fry, M.; Hersch, P.; Li, J.; Longhofer, S. Corporate Governance, Board Diversity, and Firm Value. Financ. Rev. 2003. [CrossRef]

3. Erhardt, N.L.; Werbel, J.D.; Shrader, C.B. Board of director diversity and firm financial performance. Corp. Gov. 2003. [CrossRef]

4. Catalyst. The Bottom Line: Connecting Corporate Performance and Gender Diversity; Catalyst: New York, NY, USA, 2004; ISBN 0895842440.

5. Shrader, C.B.; Blackburn, V.B.; Iles, P. Women in management and firm financial performance: An exploratory study. J. Manag. Issues 1997, 9, 355-372.

6. Smith, N.; Smith, V.; Verner, M. Do women in top management affect firm performance? A panel study of 2500 Danish firms. Int. J. Product. Perform. Manag. 2006, 55, 569-593. [CrossRef]

7. Francoeur, C.; Labelle, R.; Sinclair-Desgagné, B. Gender diversity in corporate governance and top management. J. Bus. Ethics 2008. [CrossRef]

8. Krishnan, H.A.; Park, D. A few good women-On top management teams. J. Bus. Res. 2005. [CrossRef]

9. Dezsö, C.L.; Ross, D.G. Does female representation in top management improve firm performance? A panel data investigation. Strateg. Manag. J. 2012. [CrossRef]

10. Campopiano, G.; De Massis, A.; Rinaldi, F.R.; Sciascia, S. Women's involvement in family firms: Progress and challenges for future research. J. Fam. Bus. Strateg. 2017. [CrossRef] 
11. Anderson, R.C.; Reeb, D.M. Founding-Family Ownership and Firm Performance: Evidence from the S\&P 500. J. Financ. 2003. [CrossRef]

12. Villalonga, B.; Amit, R. How do family ownership, control and management affect firm value? J. Financ. Econ. 2006. [CrossRef]

13. Minichilli, A.; Corbetta, G.; MacMillan, I.C. Top management teams in family-controlled companies: "Familiness", "faultlines", and their impact on financial performance. J. Manag. Stud. 2010. [CrossRef]

14. Miller, D.; Minichilli, A.; Corbetta, G. Is family leadership always beneficial? Strateg. Manag. J. 2013. [CrossRef]

15. Salvato, C.; Minichilli, A.; Piccarreta, R. Faster Route to the CEO Suite: Nepotism or Managerial Proficiency? Fam. Bus. Rev. 2012. [CrossRef]

16. Binacci, M.; Peruffo, E.; Oriani, R.; Minichilli, A. Are All Non-Family Managers (NFMs) Equal? The Impact of NFM Characteristics and Diversity on Family Firm Performance. Corp. Gov. Int. Rev. 2016. [CrossRef]

17. Cromie, S.; O'sullivan, S. Women as managers in family firms. Women Manag. Rev. 1999. [CrossRef]

18. Adams, R.B.; Ferreira, D. A theory of friendly boards. J. Financ. 2007. [CrossRef]

19. Harris, M.; Raviv, A. A theory of board control and size. Rev. Financ. Stud. 2008. [CrossRef]

20. Grant Thornton Women in Business: Turning promise into practice. Cult. Smart West. Eur. 2016. [CrossRef]

21. Barney, J.B. The Resource-Based Theory of the Firm. Organ. Sci. 1996. [CrossRef]

22. Katzenbach, J.R. Real change leaders. McKinsey Q. 1996. [CrossRef]

23. Carter, D.A.; D'Souza, F.; Simkins, B.J.; Simpson, W.G. The gender and ethnic diversity of US boards and board committees and firm financial performance. Corp. Gov. Int. Rev. 2010. [CrossRef]

24. Terjesen, S.; Aguilera, R.V.; Lorenz, R. Legislating a Woman's Seat on the Board: Institutional Factors Driving Gender Quotas for Boards of Directors. J. Bus. Ethics 2015. [CrossRef]

25. Adams, R.B.; Ferreira, D. Women in the boardroom and their impact on governance and performance. J. Financ. Econ. 2009. [CrossRef]

26. He, J.; Huang, Z. Board informal hierarchy and firm financial performance: Exploring a tacit structure guiding boardroom interactions. Acad. Manag. J. 2011. [CrossRef]

27. Nielsen, S.; Huse, M. The contribution of women on boards of directors: Going beyond the surface. Corp. Gov. Int. Rev. 2010. [CrossRef]

28. Randøy, T.; Thomsen, S.; Oxelheim, L. A Nordic perspective on corporate board diversity. Nord. Innov. Cent. 2006, 390, 05030.

29. Rose, C. Does female board representation influence firm performance? The Danish evidence. Corp. Gov. Int. Rev. 2007. [CrossRef]

30. Masud, M.A.K.; Nurunnabi, M.; Bae, S.M. The effects of corporate governance on environmental sustainability reporting: Empirical evidence from South Asian countries. Asian J. Sustain. Soc. Responsib. 2018. [CrossRef]

31. Campbell, K.; Mínguez-Vera, A. Gender diversity in the boardroom and firm financial performance. J. Bus. Ethics 2008. [CrossRef]

32. Martín-Ugedo, J.F.; Minguez-Vera, A. Firm Performance and Women on the Board: Evidence from Spanish Small and Medium-Sized Enterprises. Fem. Econ. 2014. [CrossRef]

33. Mínguez-Vera, A.; Martin, A. Gender and management on spanish SMEs: An empirical analysis. Int. J. Hum. Resour. Manag. 2011. [CrossRef]

34. Eagly, A.H.; Johannesen-Schmidt, M.C. The Leadership Styles of Women and Men. J. Soc. Issues 2001. [CrossRef]

35. Eagly, A.H. Achieving relational authenticity in leadership: Does gender matter? Leadersh. Q. 2005. [CrossRef]

36. Rosener, J.B. America's Competitive Secret: Utilizing Women as a Management Strategy; Oxford University Press: Oxford, UK, 1995; ISBN 978-0195080797.

37. Sandberg, K.W. An exploratory study of women in micro enterprises: Gender-related differences. J. Small Bus. Enterp. Dev. 2003. [CrossRef]

38. Montemerlo, D.; Minichilli, A.; Corbetta, G. The Determinants of Women's Involvement in Top Management Teams: Opportunities or Obstacles for family-Controlled Firms? 2nd ed.; Elgar, E., Smyrnios, K.X., Poutziouris, P.Z., Eds.; Sanjay Goel: Cheltenham, UK, 2013; ISBN 9781848443228. 
39. Kay, R.; Schlömer-Laufen, N. Gender Diversity in Top-Management Positions in Large Family and Nonfamily Businesses; Working Paper; Institut für Mittelstandsforschung: Bonn, Germany, 2016.

40. Martinez Jimenez, R. Research on Women in Family Firms: Current Status and Future Directions. Fam. Bus. Rev. 2009. [CrossRef]

41. Bjuggren, P.O.; Nordström, L.; Palmberg, J. Are female leaders more efficient in family firms than in non-family firms? Corp. Gov. 2018. [CrossRef]

42. Dumas, C. Women's pathways to participation and leadership in the family-owned firm. Fam. Bus. Rev. 1998. [CrossRef]

43. Lyman, A.; Salganicoff, M.; Hollander, B. Women in Family Business An Untapped Resource. In Family Business Sourcebook; Aronoff, C.E., Ward, J.L., Eds.; Omnigraphics: Detroit, MI, USA, 1985; pp. 46-49.

44. Salganicoff, M. Women in Family Businesses: Challenges and Opportunities. Fam. Bus. Rev. 1990. [CrossRef]

45. Scicchitano, S. The gender wage gap among Spanish managers. Int. J. Manpow. 2014. [CrossRef]

46. Chrisman, J.J.; Chua, J.H.; Litz, R.A. Comparing the agency costs of family and non-family firms: Conceptual issues and exploratory evidence. Entrep. Theory Pract. 2004. [CrossRef]

47. Gomez-Mejia, L.R.; Nuñez-Nickel, M.; Gutierrez, I. The role of family ties in agency contracts. Acad. Manag. J. 2001. [CrossRef]

48. Schulze, W.S.; Lubatkin, M.H.; Dino, R.N.; Buchholtz, A.K. Agency Relationships in Family Firms: Theory and Evidence. Organ. Sci. 2001. [CrossRef]

49. Schulze, W.S.; Lubatkin, M.H.; Dino, R.N. Altruism, agency, and the competitiveness of family firms. Manag. Decis. Econ. 2002. [CrossRef]

50. Fernández, Z.; Nieto, M.J. Internationalization Strategy of Small and Medium-Sized Family Businesses: Some Influential Factors. Fam. Bus. Rev. 2005. [CrossRef]

51. Zahra, S.A. International expansion of U.S. manufacturing family businesses: The effect of ownership and involvement. J. Bus. Ventur. 2003. [CrossRef]

52. Darmadi, S. Do women in top management affect firm performance? Evidence from Indonesia. Corp. Gov. 2013. [CrossRef]

53. Amore, M.D.; Garofalo, O.; Minichilli, A. Gender Interactions Within the Family Firm. Manag. Sci. 2014. [CrossRef]

54. Pindado, J.; Requejo, I.; de la Torre, C. Concentración de propiedad y valor de mercado en la empresa familiar: Un enfoque de gobierno corporativo. Pecunia Monográfico 2011. [CrossRef]

55. Calabrò, A.; Mussolino, D. How do boards of directors contribute to family SME export intensity? The role of formal and informal governance mechanisms. J. Manag. Gov. 2013. [CrossRef]

56. Giroud, X.; Mueller, H.M. Corporate Governance, Product Market Competition, and Equity Prices. J. Financ. 2011. [CrossRef]

57. Core, J.; Guay, W. The use of equity grants to manage optimal equity incentive levels. J. Account. Econ. 1999. [CrossRef]

58. Li, Z. Mutual monitoring and corporate governance. J. Bank. Financ. 2014. [CrossRef]

59. Dierickx, I.; Cool, K. Asset Stock Accumulation and the Sustainability of Competitive Advantage: Reply. Manag. Sci. 1989. [CrossRef]

60. Grazzi, M.; Moschella, D. Small, young, and exporters: New evidence on the determinants of firm growth. J. Evol. Econ. 2018. [CrossRef]

61. Samarakoon, S.M.; Kumara, U.E.; Gunarathne, U.G. Effect of Leverage on Profitability and Market Performance in the Manufacturing Sector of Sri Lanka: A Panel Regression Analysis. J. Account. Financ. 2014, 1, 76-87.

62. Hardwick, P.; Adams, M. The determinants of financial derivatives use in the United Kingdom life insurance industry. Abacus 1999. [CrossRef]

63. Fiegenbaum, A.; Karnani, A. Output Flexibility: A competitive Advantage for Small Firms. Strateg. Manag. J. 1991. [CrossRef]

64. Dang, C.; Li, Z.; Yang, C. Measuring firm size in empirical corporate finance. J. Bank. Financ. 2018. [CrossRef]

65. Smith, K. Profitability versus liquidity trade-off in working capital management. In Readings on the Management of Working Capital; Smith, K.V., Ed.; St. Paul West Publishing Company: St. Paul, MN, USA, 1980; pp. 549-562. 
66. Saleem, Q.; Rehman, R.U. Impacts of liquidity ratios on profitability (Case of oil and gas companies of Pakistan). Interdiscip. J. Res. Bus. 2011, 1, 95-98.

67. Niresh, J.A. Capital Structure and Profitability in Srilankan Banks. Glob. J. Manag. Bus. Res. 2012, 12, 82-90.

68. Li, F. Endogeneity in CEO power: A survey and experiment. Investig. Anal. J. 2016. [CrossRef]

69. Pindado, J.; Requejo, I.; de la Torre, C. Family control and investment-cash flow sensitivity: Empirical evidence from the Euro zone. J. Corp. Financ. 2011. [CrossRef]

70. Arellano, M.; Bond, S. Some Tests of Specification for Panel Data: Monte Carlo Evidence and an Application to Employment Equations. Rev. Econ. Stud. 1991. [CrossRef]

(C) 2018 by the authors. Licensee MDPI, Basel, Switzerland. This article is an open access article distributed under the terms and conditions of the Creative Commons Attribution (CC BY) license (http://creativecommons.org/licenses/by/4.0/). 